University of Montana

ScholarWorks at University of Montana

$5-2005$

\title{
Geography of Spring Landbird Migration Through Riparian Habitats in Southwestern North America
}

\author{
Susan K. Skagen \\ Jeffrey F. Kelly \\ Charles van Riper III \\ Richard L. Hutto \\ University of Montana - Missoula, hutto@mso.umt.edu \\ Deborah M. Finch \\ See next page for additional authors
}

Follow this and additional works at: https://scholarworks.umt.edu/biosci_pubs

Part of the Biology Commons

Let us know how access to this document benefits you.

\section{Recommended Citation}

Skagen, Susan K.; Kelly, Jeffrey F.; van Riper, Charles III; Hutto, Richard L.; Finch, Deborah M.; Krueper, David J.; and Melcher, Cynthia P., "Geography of Spring Landbird Migration Through Riparian Habitats in Southwestern North America" (2005). Biological Sciences Faculty Publications. 269.

https://scholarworks.umt.edu/biosci_pubs/269

This Article is brought to you for free and open access by the Biological Sciences at ScholarWorks at University of Montana. It has been accepted for inclusion in Biological Sciences Faculty Publications by an authorized administrator of ScholarWorks at University of Montana. For more information, please contact scholarworks@mso.umt.edu. 


\section{Authors}

Susan K. Skagen, Jeffrey F. Kelly, Charles van Riper III, Richard L. Hutto, Deborah M. Finch, David J. Krueper, and Cynthia P. Melcher 


\title{
GEOGRAPHY OF SPRING LANDBIRD MIGRATION THROUGH RIPARIAN HABITATS IN SOUTHWESTERN NORTH AMERICA
}

\author{
Susan K. Skagen ${ }^{1,7}$, Jeffrey F. Kelly ${ }^{2}$, Charles van Riper III ${ }^{3}$, Richard L. Hutto ${ }^{4}$, \\ Deborah M. Finch ${ }^{5}$, David J. KruePer ${ }^{6}$, And Cynthia P. MelcheR ${ }^{1}$ \\ ${ }^{1}$ U.S. Geological Survey, Fort Collins Science Center, Fort Collins, CO 80526 \\ ${ }^{2}$ Oklahoma Biological Survey \& Department of Zoology, University of Oklahoma, Norman, OK 73019 \\ ${ }^{3}$ U.S. Geological Survey, Southwest Biological Science Center Sonoran Desert Research Station, \\ University of Arizona, Tucson, AZ 85721 \\ ${ }^{4}$ Avian Science Center, Division of Biological Sciences, University of Montana, Missoula, MT 59812 \\ ${ }^{5}$ U.S.D.A. Forest Service, Rocky Mountain Research Station, Albuquerque, NM 87106 \\ ${ }^{6}$ U.S. Fish \& Wildlife Service Region 2, Albuquerque, NM 87103
}

\begin{abstract}
Migration stopover resources, particularly riparian habitats, are critically important to landbirds migrating across the arid southwestern region of North America. To explore the effects of species biogeography and habitat affinity on spring migration patterns, we synthesized existing bird abundance and capture data collected in riparian habitats of the borderlands region of the U.S. and Mexico. We determined the importance of geographic factors (longitude and latitude) in explaining variation in abundances and capture rates of 32 longdistance and three short-distance migrant species. Abundances and capture rates of 13 and 11 species, respectively, increased with increasing longitude, and four species' abundance and capture rates decreased with increasing longitude. Riparian associates, but not nonriparian species, were more abundant in western sites. Their abundance patterns were only weakly influenced by species biogeography. In contrast, biogeography did influence abundance patterns of nonriparian birds, suggesting that they choose the shortest, most direct route between wintering and breeding areas. We hypothesize that riparian obligate birds may, to some degree, adjust their migration routes to maximize time spent in high-quality riparian zones, but they are able to find suitable habitat opportunistically when crossing more hostile landscapes. In contrast, nonriparian birds adhere more closely to a hierarchical model in which the migratory route is determined by biogeographic constraints. Conservation of riparian habitats is necessary to meet future habitat stopover requirements of many western Neotropical migrant birds. We advocate a coordinated research effort to further elucidate patterns of distribution and habitat use so that conservation activities can be focused effectively.
\end{abstract}

Key words: desert southwest, geography, Nearctic-Neotropical migrants, riparian habitat, spring migration, stopover sites.

Geografía de la Migración de Primavera de Aves Terrestres a Través de Hábitats Riparios en el Sudoeste de Norteamérica

Resumen. Los recursos que sirven como paradas migratorias, especialmente los hábitats riparios, son críticamente importantes para las aves migratorias terrestres a través de la región árida del sudoeste de Norteamérica. Para explorar los efectos de la biogeografía de las especies y la afinidad de hábitat sobre los patrones de migración de primavera, sintetizamos los datos existentes de abundancia y capturas de aves colectados en hábitats riparios en la zona fronteriza entre Estados Unidos y México. Determinamos la importancia de factores geográficos (latitud y longitud) en explicar la variación en las abundancias y en las tasas de captura de 32 especies migratorias de larga distancia y 3 de corta distancia. Las abundancias y tasas de captura de 13 y 11 especies, respectivamente, aumentaron con el aumento de la longitud, y cuatro especies mostraron una disminución con el aumento de la longitud. Las aves asociadas a los ambientes riparios fueron más abundantes en los sitios del oeste que las especies no riparias, y su abundancia sólo se vio levemente influenciada por la biogeografía de las especies. De modo contrastante, la biogeografía sí influenció los patrones de abundancia de las especies de aves no riparias, lo que sugiere que éstas escogieron la ruta más corta y directa entre las áreas de invernada y de reproducción. Proponemos la hipótesis de que las aves de hábitat ripario obligatorias pueden, hasta cierto grado, ajustar sus rutas migratorias para maximizar el tiempo en zonas riparias de alta calidad, pero

Manuscript received 25 August 2004; accepted 4 February 2005.

${ }^{7}$ E-mail: susan_skagen@usgs.gov 
también son capaces de encontrar hábitats adecuados de manera oportunista al cruzar paisajes más hostiles. De modo contrastante, las aves no riparias se adhieren más cercanamente a un modelo jerárquico en el cual la ruta migratoria es determinada por restricciones biogeográficas. La conservación de los hábitats riparios es necesaria para cumplir los requerimientos futuros de las paradas durante la migración de muchas aves migratorias Neotropicales del oeste. Abogamos por un esfuerzo de investigación coordinado para elucidar los patrones de distribución y de uso de hábitat de manera que las actividades para la conservación puedan ser enfocadas de manera eficiente.

\section{INTRODUCTION}

The critical importance of migration stopover resources to en route landbirds in the western US has recently come to the forefront of avian research and conservation (Hutto 1998, 2000, Skagen et al. 1998, Yong et al. 1998, Kelly et al. 1999, Finch and Yong 2000). Long-distance migration is energetically costly, and migratory birds either must refuel frequently or carry large fat reserves while traveling between wintering and breeding areas. Loss of suitable stopover habitat may increase competition for limited food resources, increase energetic stress, inhibit migration, and increase mortality, ultimately reducing reproductive success on the breeding grounds (Evans et al. 1991, Moore and Yong 1991, Moore et al. 1995). Petit (2000) noted that identification of high-priority stopover sites and migration habitats critical to the long-term persistence of migrating species is necessary before comprehensive strategies for species protection can be completed. Effective conservation planning for Neotropical migrant landbirds must incorporate information on migration as well as breeding and wintering resource needs.

Recent evidence suggests that several attributes of migration are tied to species-specific biogeographic features, which include the size of its breeding range and distance between wintering and breeding areas. For example, abundances and variation in abundances of landbirds at stopover sites in the southwestern U.S. are strongly related to the proximity of those sites to species' breeding ranges (Skagen et al. 1998, Kelly et al. 1999). Geographic locations used by many landbirds during spring migration may also vary regionally depending on location of wintering areas. Western Mexico comprises a substantial portion of the wintering range of many landbird species (Hutto 1980, 1985) that breed across the western U.S. and Canada. These species, such as vireos and flycatchers, winter along the Pacific coast of Mexico west and south of the Sierra Madre Occidental from southern Sonora to Guatemala (Barlow 1980 [vireos], Fitzpatrick 1980 [flycatchers], Hutto 1980, 1992). Further, genetically distinct races of some migrants that are broadly distributed in their breeding ranges, such as Common Yellowthroat (Geothlypis trichas) and Yellow-breasted Chats (Icteria virens), show segregation in wintering areas, with western breeders wintering in western Mexico and eastern breeders wintering along the Atlantic coast of Mexico and Central America (Lovette et al. 2004). Western bird populations wintering in western Mexico may require migration stopover sites within a relatively restricted area in the southwestern U.S. and northern Mexico as they travel north along the western edge of the Sierra Madre Occidental.

In the arid southwestern U.S., many migrant species, including western wood warblers, depend on riparian vegetation to provide stopover resources in spring (Kelly and Hutto 2005) even though it comprises less than $1 \%$ of the western landscape (Knopf et al. 1988, Skagen et al. 1998). Some landbirds are obligate riparian species whereas others use riparian vegetation facultatively (Dobkin and Wilcox 1986). Anthropogenic disturbances to western riparian ecosystems, such as modification of natural flow regimes, development in flood plains, grazing, conversion of lands to agriculture, and forest clearing, are pervasive and increasing as a result of human population growth in the region (Fleischner 1994, Poff et al. 1997, Skagen et al., in press). The resulting loss and modification of native riparian forests reduces migration stopover resources and can ultimately contribute to future population declines in western birds (Ohmart 1994, Moore et al. 1995). Protection, management, and restoration of these sensitive and threatened habitats - and the species that depend on them-are important concerns for many federal and state agencies and nongovernmental organizations (Rich et al. 2004, The Nature Conservancy 2004).

This project represents a synthesis of several western migration studies, is an initial step in 


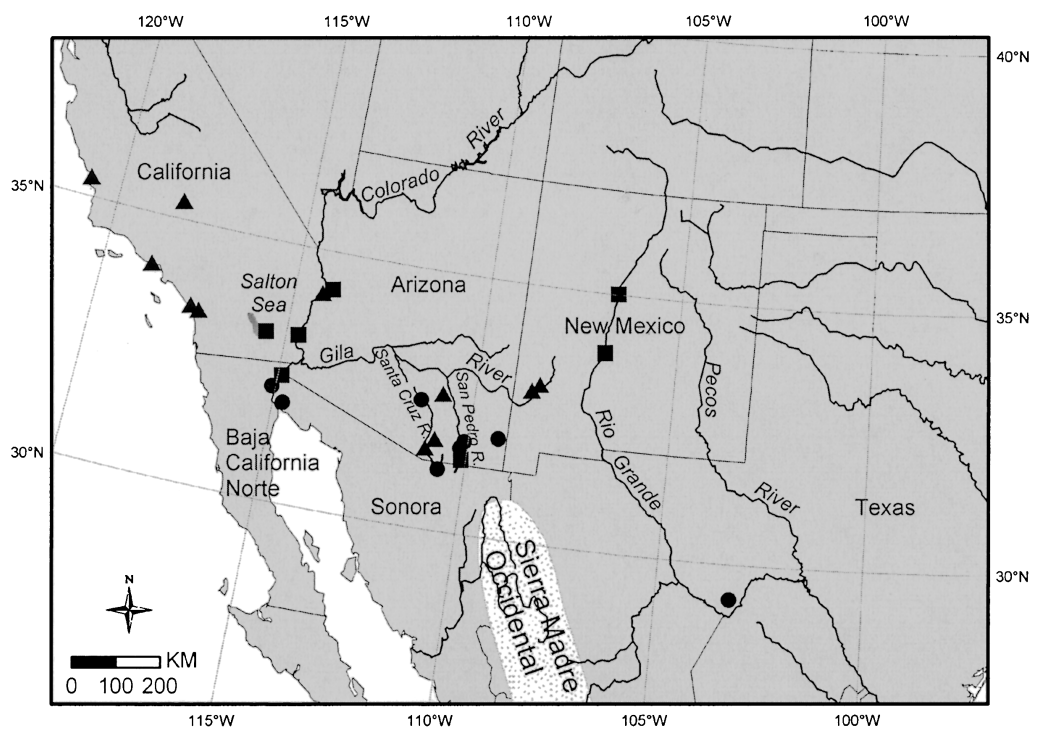

FIGURE 1. Locations of survey and banding sites in southwestern United States and northern Sonora, Mexico, 1975-2003. Circles represent survey sites, triangles represent banding sites, and squares represent sites with both survey and banding efforts.

identifying regions and landscapes important during migration stopover, and may enhance efforts for conserving migration habitats of landbirds that breed in western North America. Our objectives were (1) to identify geographic trends in abundance and capture rates of avian species using riparian habitats across the southwestern U.S. and northern Sonora, Mexico, during spring migration, and (2) to explore the relative importance of species biogeography and riparian affinity and their influence on bird distribution during migration.

\section{METHODS}

\section{DATA MANAGEMENT}

Participating scientists contributed bird survey (abundance) data, capture data from mist-netting (banding) efforts, and habitat information from work conducted in Texas, New Mexico, Arizona, California, and Sonora, Mexico (Fig. 1). We pooled data for species whose taxonomies had changed since data were collected and for species recorded at more than one taxonomic level (i.e., species and subspecies). Specifically, Pacific-Slope Flycatcher (Empidonax difficilis) and Cordilleran Flycatcher (E. occidentalis) were pooled as Western Flycatcher (E. difficilis), Cassin's Vireo (Vireo cassinii) and Plumbeous Vireo (V. plumbeus) as Solitary Vireo (V. solitarius),
Audubon's Warbler (Dendroica coronata auduboni) and Myrtle Warbler (D. c. coronata) as Yellow-rumped Warbler (D. coronata), Bullock's Oriole (Icterus bullockii) and Baltimore Oriole (I. galbula) as Northern Oriole (I. galbula), and Mountain White-crowned Sparrow (Zonotrichia leucophrys oriantha) and Gambel's White-crowned Sparrow (Z. l. gambelii) as White-crowned Sparrow (Z. leucophrys). We developed standardized habitat categories (riparian, mesquite, grassland, desert scrub, montane or upland forest, urban, and other) and chose riparian habitats for the geographic analyses because they were the best-sampled habitats across the study region. We defined riparian habitats as the vegetation communities dominated by shrubs or trees associated with perennial, intermittent, or ephemeral surface or subsurface water (Krueper 1993). We acquired locational data (latilong or UTM) for all sites, either from contributors, maps, or from MapTech (1989-2005).

We calculated the average number of birds detected per point at each site during spring (1 April to 12 May) based on point count surveys. For two studies that reported birds per transect or birds per 10 ha, we estimated what the equivalent area would be in terms of 50-m radius points and converted bird abundances to number of birds per point (Dobkin and Rich 1998). For 
spring capture data, we calculated number of captures per 100 mist-net hours for each site. We eliminated all records of 'flyovers' and birds recaptured within one week of initial capture.

For each survey site, bird species that comprised $90 \%$ of the sightings were categorized by their migration distance (using range maps in the Birds of North America [BNA] species accounts, Poole and Gill 1992-2003). We categorized species as long-distance migrants (L) if all or the majority of a species breeds north of $45^{\circ} \mathrm{N}$ latitude, short-distance migrants (S) if a portion of the species' population breeds only as far north as $41^{\circ} \mathrm{N}$ latitude, and resident or local breeders if most individuals breed locally (some breed as far north as $36^{\circ} \mathrm{N}$ latitude).

We selected 32 species of long-distance migrants and three species of short-distance migrants that were commonly detected during surveys or captured at banding sites. We categorized breeding and wintering distributions of the selected species relative to longitudinal gradients using range maps in the BNA accounts (Table $1)$. We also defined the northern and eastern limits of the breeding ranges; for species with disjunct breeding ranges, we defined eastern extent of the western portion of the breeding range. Wintering distributions were categorized by west-to-east extent (Table 1).

Referring to habitat descriptions in the BNA accounts, we also assigned all species to one of three 'riparian affinity' categories: (1) riparian obligates and 'associates,' generally linked with riparian habitats (emphasis on western portion of species' range for species that extend east of $100^{\circ} \mathrm{W}$ longitude), (2) not considered a riparianassociated species, per se, but often found in riparian woodlands or other riparian habitats, and (3) generally not associated with riparian habitats. In some contexts, we refer to riparian affinity categories 2 and 3 as 'nonriparian species.' For five species with little or no information on migration habitat use (Table 1), we assumed a similar degree of riparian association during migration as exhibited during the breeding season (Greenberg 1983).

\section{STATISTICAL ANALYSES}

Modeling avian abundance and capture rates. We described geographical patterns of several summary metrics, count totals, and capture rates of 35 species using data collected in riparian habitats west of $100^{\circ} \mathrm{W}$ longitude. For each anal- ysis, we used AIC model-selection techniques and model averaging (Burnham and Anderson 2002) to determine the relative importance of several explanatory variables and to estimate the magnitude of their effects. Because this work is exploratory, we modeled all combinations of independent variables. Relative abundance estimates of birds were $\log _{\mathrm{e}}$-transformed (ln) to improve normality and stabilize variance.

Although we were primarily interested in geographic variables (longitude and latitude) to explain spatial patterns in bird abundances and capture rates during migration, we identified several additional covariates that potentially confounded the resulting spatial patterns. Therefore, in addition to longitude and latitude, we considered the following explanatory variables for inclusion in candidate models to explain survey data: effort (total number of survey-point visits or number of mist-net hours, ln-transformed), median date of surveys, extent of canopy, elevation, and riparian habitat type. Extent of canopy was classified as $1=$ sparse structural canopy, primarily shrubs and small, scattered trees; 3 = extensive tree canopy (gallery forests); and 2 = intermediate between canopy classes 1 and 3. Riparian type was categorized as 1 = low elevation $(<560 \mathrm{~m})$ or mainstem rivers, $2=$ higher elevation tributary rivers, and 3 = higher elevation tributary creeks.

We ran Pearson and Spearman rank correlations for all possible variable pairs and retained only one variable from pairs that were strongly correlated $(|r|>0.50)$. For survey sites, longitude and elevation were negatively correlated $\left(r_{14}=-0.75\right)$ as were longitude and riparian type $\left(r_{14}=-0.77\right)$; western sites were predominantly low-elevation, mainstem river habitats, whereas higher-elevation, lower-order rivers occurred farther east. We retained longitude for inclusion in models because it was our primary variable of interest. Survey effort and extent of canopy were positively correlated $\left(r_{14}=0.65\right)$; several studies focused on gallery cottonwood (Populus spp.) forests. To decide which of these two variables to include in the candidate models for each of the selected species, we ran univariate linear regression models (species abundance by $\ln$ [effort]; species abundance by canopy) and chose the model with the lowest residual sum of squares (RSS). We followed a similar process to determine whether to use median date or the 
TABLE 1. Commonly detected migrant species categorized with respect to breeding and wintering distributions and riparian affinity.

\begin{tabular}{|c|c|c|c|c|c|c|}
\hline Species & $\begin{array}{c}\text { Species } \\
\text { code }\end{array}$ & $\begin{array}{l}\text { Breeding } \\
\text { distribu- } \\
\text { tion } \\
\text { category }\end{array}$ & $\begin{array}{l}\text { Northern } \\
\text { extent } \\
\text { (degrees } \\
\text { latitude) }\end{array}$ & $\begin{array}{c}\text { Eastern } \\
\text { extent } \\
\text { (degrees } \\
\text { longi- } \\
\text { tude) }\end{array}$ & $\begin{array}{l}\text { Winter } \\
\text { distribu- } \\
\text { tion } \\
\text { categoryd }\end{array}$ & $\begin{array}{l}\text { Riparian } \\
\text { affinity } \\
\text { category }\end{array}$ \\
\hline Western Wood-Pewee (Contopus sordidulus) & WEWP & 1 & 66 & 97 & 3 & 2 \\
\hline Gray Flycatcher (Empidonax wrightii) & GRFL & 1 & 51 & 105 & 2 & 3 \\
\hline Hammond's Flycatcher (E. hammondii) & HAFL & 1 & 67 & 103 & 3 & 3 \\
\hline Dusky Flycatcher (E. oberholseri) & DUFL & 1 & 60 & 104 & 2 & 3 \\
\hline Western Flycatcher $(E \text {. difficilis })^{\mathrm{f}}$ & WEFL & 1 & 60 & 104 & 2 & 1 \\
\hline Western Kingbird (Tyrannus verticalis) & WEKI & 1 & 55 & 93 & 1 & 2 \\
\hline Bell's Vireo (Vireo bellii) & BEVI & 3 & 48 & 86 & 1 & 1 \\
\hline Solitary Vireo $(V \text {. solitarius })^{\mathrm{f}}$ & SOVI & 2 & 54 & 103 & 1 & 2 \\
\hline Warbling Vireo (V. gilvus) & WAVI & 2 & 65 & 103 & 1 & 2 \\
\hline \multicolumn{7}{|l|}{ Northern Rough-winged Swallow (Stelgidopteryx } \\
\hline serripennis) & NRWS & 3 & 55 & 50 & 2 & 1 \\
\hline Ruby-crowned Kinglet (Regulus calendula) & RCKI & 2 & 68 & 103 & 3 & 3 \\
\hline Hermit Thrush (Catharus guttatus) & HETH & 2 & 67 & 102 & 3 & 2 \\
\hline Orange-crowned Warbler (Vermivora celata) & OCWA & 2 & 68 & 103 & 3 & 2 \\
\hline Nashville Warbler (V. ruficapilla) & NAWA & 2 & 57 & 112 & 2 & 3 \\
\hline Yellow Warbler (Dendroica petechia) & YWAR & 3 & 67 & 54 & 2 & 1 \\
\hline Yellow-rumped Warbler $(D$. coronata $)$ & YRWA & 2 & 70 & 102 & 3 & 3 \\
\hline Black-throated Gray Warbler (D. nigrescens) & BTYW & 1 & 52 & 102 & 2 & 3 \\
\hline Townsend's Warbler (D. townsendi) & TOWA & 1 & 67 & 113 & 3 & 3 \\
\hline Hermit Warbler (D. occidentalis) & HEWA & 1 & 48 & 119 & 2 & 3 \\
\hline MacGillivray's Warbler (Oporornis tolmiei) & MGWA & 1 & 61 & 101 & 2 & 2 \\
\hline Common Yellowthroat (Geothlypis trichas) & COYE & 3 & 62 & 54 & 3 & 1 \\
\hline Wilson's Warbler (Wilsonia pusilla) & WIWA & 2 & 70 & 105 & 2 & 1 \\
\hline Yellow-breasted Chat (Icteria virens) & $\mathrm{YBCH}$ & 3 & 55 & 102 & 2 & 1 \\
\hline Western Tanager (Piranga ludoviciana) & WETA & 1 & 65 & 100 & 2 & 3 \\
\hline Green-tailed Towhee (Pipilo chlorurus) & GTTO & 1 & 48 & 103 & 3 & 3 \\
\hline Spotted Towhee ( $P$. maculatus) & SPTO & 1 & 53 & 98 & 3 & 3 \\
\hline Chipping Sparrow (Spizella passerina) & CHSP & 3 & 67 & 64 & 3 & 3 \\
\hline Brewer's Sparrow (S. breweri) & BRSP & 1 & 62 & 102 & 3 & 3 \\
\hline Song Sparrow (Melospiza melodia) & SOSP & 3 & 62 & 102 & 3 & 1 \\
\hline Lincoln's Sparrow (M. lincolnii) & LISP & 2 & 67 & 104 & 3 & 1 \\
\hline White-crowned Sparrow (Zonotrichia leucophrys) & WCSP & 2 & 71 & 102 & 3 & 3 \\
\hline Black-headed Grosbeak (Pheucticus melanocephalus) & BHGR & 1 & 55 & 97 & 2 & 2 \\
\hline Lazuli Bunting (Passerina amoena) & LAZB & 1 & 53 & 98 & 1 & 2 \\
\hline Northern Oriole (Icterus galbula) & NOOR & 1 & 52 & 93 & 2 & 1 \\
\hline Lesser Goldfinch (Carduelis psaltria) & LEGO & 1 & 46 & 97 & 3 & 2 \\
\hline
\end{tabular}

${ }^{a}$ Breeding distribution category: 1 = western North America only; 2 = western North America and eastern Canada (sometimes including extreme northern or northeastern U.S.); 3 = more easterly distributions, generally continent- or U.S.-wide, but one species (Bell's Vireo) is limited to south-central U.S.

$\mathrm{b}$ Northern-most latitude of breeding range.

${ }^{c}$ Eastern-most longitude of breeding range.

d Winter distribution category: $1=$ primarily Mexico, west of the Sierra Madre Occidental or south of the Central Volcanic Belt, and along the Pacific Coast; 2 = primarily in Mexico or Central America, with at least one third of the Mexican distribution as in category 1 and the remainder more easterly; $3=$ significantly more easterly distribution than in categories 1 and 2, either throughout Mexico or extending into Central and South America (based on Howell and Webb 1995).

e Riparian affinity category: 1 = riparian obligates and 'associates', generally linked with riparian habitats; 2 $=$ not considered a riparian-associated species, per se, but often found in riparian woodlands or other riparian habitats; and 3 = generally not associated with riparian habitats (based on BNA accounts). For five species with little or no information on migration habitats (Western Kingbird, Northern Rough-winged Swallow, Townsend's Warbler, Spotted Towhee, and White-crowned Sparrow), we assumed a similar degree of riparian association during migration as exhibited during the breeding season.

${ }^{\mathrm{f}}$ We pooled data for species whose taxonomies had changed since data were collected. 
quadratic of median date, using the form with the lowest AIC value.

Explanatory variables considered for inclusion in candidate models for capture data were longitude, latitude, effort (number of mist-net hours, ln-transformed), and median date of capture efforts. Effort and median date were correlated $\left(r_{17}=-0.58\right)$. For each species, we decided which of these variables (effort, median date, or the quadratic of median date) to incorporate into the final set of candidate models by running regression models and choosing the model with the lowest AIC value.

We determined the magnitude of effect for variables and covariates by model-averaging coefficients across all models containing the variable of interest (Burnham and Anderson 2002; Eq. 5.7). Model averaging is a valuable approach to evaluating relationships when there is a high degree of model uncertainty (several models within the set of candidate models have substantial weight; Burnham and Anderson 2002). Because analyses yielded 235 speciesvariable combinations, we developed a method for scoring whether a variable (or covariate) had an effect on the abundance or capture rates of a given species. We calculated $95 \%$ and $90 \%$ confidence intervals (CI) and scored the magnitude of each effect. Each species-variable combination was assigned an effect score of 0 (no effect) if the $90 \%$ CI clearly spanned zero, 1 (small effect) if the $90 \%$ CI did not span zero, and 2 (large effect) if the $95 \%$ CI did not span zero. When either the survey or capture data yielded many zeros $(>50 \%)$ for a given species $(n=5$ in survey dataset, $n=11$ in capture dataset), we also ran logistic regressions to compare with the linear regression results. If the effect of longitude was similar between the two regression approaches, we reported the linear regression coefficients and used them in subsequent analyses; otherwise, we dropped the species from further analyses.

Species biogeography and riparian affinity. We also explored the influence of breeding and wintering distribution and habitat affinity on the longitudinal patterns of count totals and capture rates during spring migration for 35 species. To do so, we regressed a derived response variable (coefficients for longitude from the previous analyses; higher values represent greater abundances or capture rates in the west) against four predictor variables: (1) northern extent of breeding distri- bution ( ${ }^{\circ} \mathrm{N}$ latitude), (2) eastern extent of breeding distribution ( ${ }^{\circ} \mathrm{W}$ longitude), (3) winter distribution category, and (4) riparian affinity, again in balanced sets of candidate models. We then model-averaged coefficients, computed $95 \%$ and $90 \%$ confidence intervals, and scored the effect of each variable as described above. All analyses were conducted in SYSTAT 9.1. Means \pm SE are reported unless otherwise specified.

For post-hoc analyses on survey sites in the U.S., we used the National Land Cover Data (Multi-Resolution Land Characteristics Consortium 2000) to quantify area of riparian habitat in $1^{\circ}$ latilong blocks encompassing 10 survey sites in the United States. The National Land Cover Data are derived from early to mid-1990s Landsat Thematic Mapper satellite data with spatial resolution of $30 \mathrm{~m}$. We used the classifications of "woody wetlands" and "deciduous forest" as a best indication of riparian forests (M. L. Scott, pers. comm.). Woody wetlands are defined as "areas where forest or shrubland vegetation accounts for $25 \%-100 \%$ of the cover and the soil or substrate is periodically saturated with, or covered with, water," and deciduous forest is defined as "areas dominated by trees generally greater than 5-m tall, and greater than $20 \%$ of total vegetation cover. More than $75 \%$ of the tree species shed foliage simultaneously in response to seasonal change."

\section{RESULTS}

Avian survey data were contributed from 15 riparian sites ranging geographically from the Salton Sea, California, to Big Bend National Park, Texas (Fig. 1). During spring migration, all sites varied in species richness (range 43-178 species), mean abundances of birds (range 6.9-24.8 birds per point), and percentage of birds that were long-distance migrants (range 26\%-89\%) and migrants in general (range $47 \%-94 \%$; Table 2 ). The most common species across all sites were Mourning Doves (Zenaida macroura), Red-winged Blackbirds (Agelaius phoeniceus), Brown-headed Cowbirds (Molothrus ater), and Yellow-rumped Warblers. Song Sparrows (Melospiza melodia), Common Yellowthroats, and Yellow Warblers (Dendroica petechia) were often common at the more westerly sites. Species composition also varied considerably among sites. Abundances are presented for 35 species at each of the study sites, progressing from west to east across the study range; abundances for 
TABLE 2. Avian survey effort during spring migration (1 Apr to 12 May), number of species, bird abundance, and percentage of migrants (long-distance migrants $[\mathrm{L}]$ and all migrants $[\mathrm{L}+\mathrm{S}]$ ) at bird survey sites across southwestern United States and northern Sonora, Mexico.

\begin{tabular}{|c|c|c|c|c|c|c|c|c|}
\hline Study site & Site Code & $\begin{array}{l}\text { Longi- } \\
\text { tude } \\
\text { (degrees } \\
\text { W) }\end{array}$ & $\begin{array}{l}\text { Ripar- } \\
\text { ian } \\
\text { type }\end{array}$ & $\begin{array}{l}\text { Number } \\
\text { of seasons } \\
\text { (years) }\end{array}$ & $\begin{array}{l}\text { Total point } \\
\text { counts, } \\
\text { number } \\
\text { of visits }\end{array}$ & $\begin{array}{l}\text { Number } \\
\text { of } \\
\text { species }\end{array}$ & $\begin{array}{l}\text { Number } \\
\text { of birds } \\
\text { per point } \\
\text { count }\end{array}$ & $\begin{array}{c}\text { Percent } \\
\text { migrants } \\
(\mathrm{L}, \mathrm{L}+\mathrm{S})\end{array}$ \\
\hline $\begin{array}{l}\text { Salton Sea, Cali- } \\
\text { fornia }\end{array}$ & SSCA & 115.5 & 1 & 1 (1999) & 152,8 & 101 & 14.0 & 86,88 \\
\hline $\begin{array}{l}\text { Baja California, } \\
\text { Mexico }\end{array}$ & BCMX & 115.1 & 1 & $2(2000-2001)$ & 72,4 & 46 & 9.0 & 50,55 \\
\hline Sonora, Mexico & CRHI & 114.9 & 1 & $1(2002)$ & 256,1 & 103 & 19.9 & 64,73 \\
\hline Sonora, Mexico & CRVR & 114.7 & 1 & $1(2000)$ & 67,3 & 72 & 24.8 & 89,94 \\
\hline $\begin{array}{l}\text { Colorado River, } \\
\text { Cibola NWR, } \\
\text { Arizona }\end{array}$ & CIAZ & 114.7 & 1 & $5(1999-2003)$ & 480,30 & 81 & 15.5 & 47,52 \\
\hline $\begin{array}{l}\text { Colorado River, } \\
\text { Bill Williams } \\
\text { NWR, Arizona }\end{array}$ & BWAZ & 114.0 & 1 & 4 (1999-2002) & 224,16 & 82 & 16.6 & 40,61 \\
\hline $\begin{array}{l}\text { Santa Cruz River, } \\
\text { Arizona }\end{array}$ & SCAZ & 111.3 & 2 & $3(2001-2003)$ & 64,8 & 47 & 15.0 & 61,78 \\
\hline $\begin{array}{l}\text { Santa Cruz River, } \\
\text { Sonora, Mexico }\end{array}$ & SCMX & 110.7 & 2 & $1(2001)$ & 26,1 & 50 & 16.0 & 39,71 \\
\hline $\begin{array}{l}\text { Southeast Arizona, } \\
\text { high elevation } \\
\text { riparian }\end{array}$ & HEAZ & 110.2 & 3 & $\begin{array}{l}4(1989,1991,1993, \\
1994)\end{array}$ & 838,22 & 131 & 6.9 & 48,68 \\
\hline $\begin{array}{l}\text { San Pedro River, } \\
\text { Arizona; low el- } \\
\text { evation riparian }\end{array}$ & LEAZ & 110.1 & 2 & $\begin{array}{l}4(1989,1991,1993, \\
1994)\end{array}$ & 3587,22 & 178 & 17.8 & 49,68 \\
\hline $\begin{array}{l}\text { San Pedro River, } \\
\text { Arizona }\end{array}$ & SPAZ & 110.1 & 2 & 6 (1986-1991) & $1925^{b}, 36$ & 174 & 16.6 & 44,63 \\
\hline $\begin{array}{l}\text { Chiricahua Moun- } \\
\text { tains, Arizona }\end{array}$ & CMAZ & 109.3 & 3 & $2(1975,1978)$ & $72^{c}, 1$ & 43 & 9.9 & 44,47 \\
\hline $\begin{array}{l}\text { Rio Grande, } \\
\text { Bosque del } \\
\text { Apache NWR, } \\
\text { New Mexico }\end{array}$ & BANM & 106.9 & 2 & 5 (1994-1998) & 540,25 & 107 & 12.2 & 68,85 \\
\hline $\begin{array}{l}\text { Rio Grande, Rio } \\
\text { Grande Nature } \\
\text { Center, New } \\
\text { Mexico }\end{array}$ & RGNM & 106.7 & 2 & 3 (1994-1996) & 774,37 & 128 & 15.5 & 78,83 \\
\hline $\begin{array}{l}\text { Big Bend National } \\
\text { Park, Texas }\end{array}$ & BBNP & 103.2 & 2 & 3 (1995-1997) & 90,6 & 66 & 11.5 & 26,62 \\
\hline
\end{tabular}

a Riparian type: $1=$ low elevation $(<560 \mathrm{~m})$ or mainstem rivers, $2=$ higher elevation tributary rivers, and $3=$ higher elevation tributary creeks.

b Data transformed from transects to point count equivalents.

c Summary data transformed to point count equivalents.

any one species ranged from 0 to 20.9 birds per 10 point counts (Table 3 ). Site-specific abundances and percentage of representation for all species are available from SKS.

Avian capture data were contributed from 18 riparian sites, ranging geographically from southern California to Texas; site locations ranged between $31-36^{\circ} \mathrm{N}$ latitude and $106-$ $121^{\circ} \mathrm{W}$ longitude (Fig. 1). Mist-net hours totaled 44032 across all sites (mean $2446 \pm 1032$, range 60-14 099) with the greatest effort at sites along the Rio Grande, New Mexico, and at California sites. Capture rates averaged 73.7 birds per 100 mist-net hours ( \pm 13.6 , range 11.6238.3). Capture rates were lowest at sites with the most extensive effort $(r=0.48$, df $=17$, regression coefficient $=0.64 \pm 0.29)$, presumably because the effort extended into times of the season or day when capture rates were lower. Capture rates were highest when the timing of mist-netting effort coincided with peak migration of abundant species. 
Influence of predictor variables on avian abundance and capture rates. Number of species at survey sites was best predicted by canopy cover (regression coefficient $=34.77 \pm 10.34$, large effect, $r^{2}$ of global model $=0.57$ ), recognizing that canopy cover and survey effort were strongly correlated. Percent of birds that were long-distance migrants increased with increasing latitude (regression coefficient $=7.02 \pm 3.16$, large effect, $r^{2}$ of global model $=0.47$ ). There were no other effects of predictor variables (longitude, latitude, extent of canopy or survey effort, and median date or its quadratic) on these or other survey summary variables (number of birds per point count, percent migrants, number of long-distance migrants per point count, total number of migrants per point count).

For species with many $(>50 \%)$ zero counts, effects of longitude on survey data were similar in linear and logistic regression models for four of five species, thus we retained linear regression results for Dusky Flycatcher (Empidonax oberholseri), Hammond's Flycatcher (Empidonax hammondii), Hermit Warbler (Dendroica occidentalis), and Western Flycatcher; we eliminated Spotted Towhee from further analyses of survey data. For species with many zeros in capture analyses, effects of longitude were also similar between linear and logistic-regression models for nine of 11 species. We retained linear regression results for Northern Oriole, Western Kingbird (Tyrannus verticalis), Bell's Vireo (Vireo bellii), Gray Flycatcher (Empidonax wrightii), Townsend's Warbler (Dendroica townsendi), Western Tanager (Piranga ludoviciana), Western Wood-Pewee (Contopus sordidulus), Solitary Vireo, and Brewer's Sparrow (Spizella breweri), and omitted Hermit Warbler and Northern Rough-winged Swallow (Stelgidopteryx serripennis) from further capture analyses.

In general, the influence of four predictor variables (longitude, latitude, and two covariates) on abundances of 34 species in survey data were substantial, as illustrated by coefficients of determination $\left(r^{2}\right)$ of global models (mean $r^{2}=$ $0.56 \pm 0.03$, range $0.14-0.83$; Table 4$)$. Abundances of 13 species (38\% of 34 species) increased with increasing longitude; the effect of longitude was large for 10 of these species and small for three (Table 4; Fig. 2). Song Sparrow, Common Yellowthroat, and Warbling Vireo (Vireo gilvus) were among the species with the greatest positive regression coefficients for lon- gitude, indicating greater abundances in western sites. Longitude had no observed effect on abundances of 17 species (50\%), such as Yellowrumped Warbler and White-crowned Sparrow (Fig. 2). Abundances of four species (12\%) increased with decreasing longitude, indicating decreasing abundance in western sites, as illustrated for Black-headed Grosbeak (Pheucticus melanocephalus) and Chipping Sparrow (Spizella passerina). Latitude was correlated with abundances of nine species, positive for five and negative for four (Table 4). Covariates also influenced abundances. Abundances of eight species, including Yellow Warbler, Yellow-breasted Chat, and Northern Oriole, were positively correlated with extent of canopy. Survey effort was positively related to abundances of 15 species, and timing of surveys (median date) influenced abundance estimates of six species (three positively and three negatively).

Global models for capture rates of 33 species included longitude, latitude, and covariates of survey effort and median date (or the quadratic of median date). In general, these variables were useful in predicting capture rates, again as illustrated by the coefficients of determination $\left(r^{2}\right)$ of the global models for the 33 species (mean $r^{2}=$ $0.41 \pm 0.04$, range 0.07-0.86; Table 5). Capture rates of 11 species increased with increasing longitude (were greater in the west); again, Song Sparrow, Common Yellowthroat, and Warbling Vireo were among those with the greatest positive regression coefficients for longitude. Capture rates of four species increased with decreasing longitude. Latitude had an effect on capture rates of only 5 species, positive for one and negative for four. Mist-netting effort or timing (median date) accounted for substantial variation in capture rates of 16 species.

Longitudinal and latitudinal trends in abundances and capture rates were fairly consistent on a species-by-species basis (Tables 4 and 5). For the effect of longitude, 21 species ( $66 \%$ of 32 species) scored similarly in analyses of both survey and capture data, exhibiting a positive trend ( 1 or 2$)$, a negative trend $(-1$ or -2$)$, or no trend (0). Ten species showed a trend in one data type and none in the other, and only one species (Black-headed Grosbeak) showed opposite (but small) trends with respect to longitude. The effects of latitude were even more consistent, with 25 species (78\%) showing consistent trends between the two data types, seven exhibiting a trend in one analysis and 


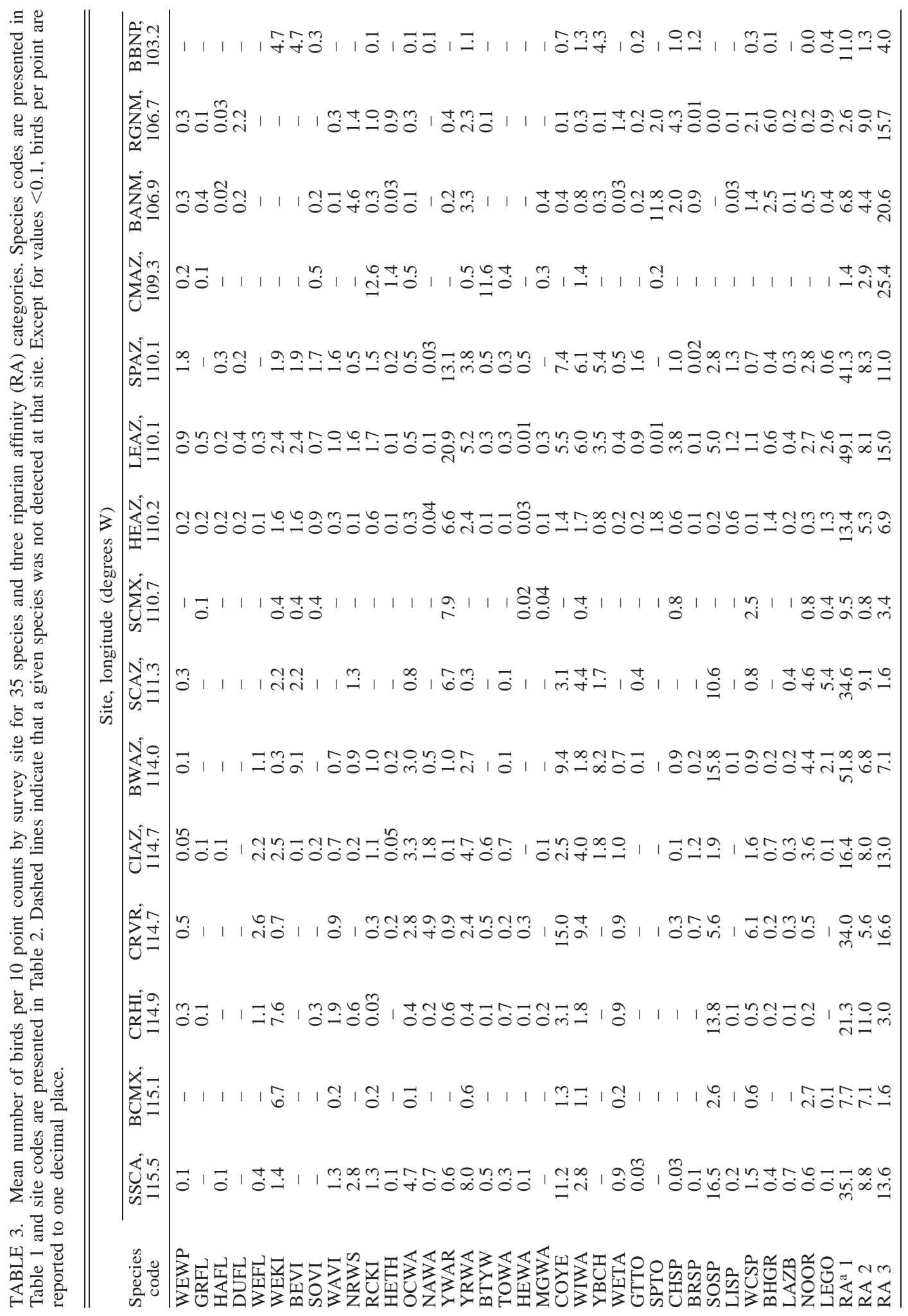


none in the other, and no species exhibiting opposite trends.

Influence of species biogeography and habitat affinity on migration patterns. Riparian affinity influenced geographic patterns of abundance and capture rates during migration. In both survey and capture data, riparian associates (riparian affinity category 1 ) were more abundant at sites in the west than farther east (as illustrated by greater regression coefficients for longitude in previous analyses) than were nonriparian species (Table 6). Mean longitude regression coefficients for riparian associates were $0.15 \pm 0.05$ $(n=10)$ and $0.11 \pm 0.05(n=9)$ for survey and capture data, contrasting with coefficients for nonriparian species (riparian affinity category 3; mean coefficient $=0.03 \pm 0.03, n=$ 14 , and $-0.003 \pm 0.03, n=14$, for survey and capture data, respectively).

Species biogeography was also correlated with migration abundance patterns in the survey analyses. In general, species with more westerly breeding ranges had higher migration counts in the western sites than did species whose ranges extended further east, as illustrated by the large positive effect of eastern extent of breeding range $\left({ }^{\circ} \mathrm{W}\right.$ longitude) on longitude regression coefficients from previous analyses (where higher values represent greater abundances in the west, Table 6). This trend was not apparent in the capture data.

When riparian associates were evaluated independently, none of the three biogeographic factors influenced west-east abundance patterns from migration surveys (all effect scores of 0 ). However, all three geographic factors influenced west-east migration abundance patterns of species in riparian affinity categories 2 and 3 (Table 6 ). Birds that breed farther north, or have more westerly breeding ranges or wintering distributions, tended to exhibit greater abundances at more westerly sites during migration. The capture analyses revealed no similar effects of biogeographic factors on capture rates.

Because geographic factors did not appear to influence west-east abundance patterns of riparian birds, we conducted post-hoc analyses to de- termine whether extent of riparian habitat in landscapes surrounding the sites influenced riparian bird abundances. We estimated the area of riparian forest in the surrounding landscape for a subset of 10 survey sites with available National Land Cover Data (NLCD). The amount of riparian cover in the $1^{\circ}$ latilong blocks surrounding the sites ranged from $0.01 \%$ to $0.49 \%$. Total abundances of 10 riparian species were positively related to the percent cover of riparian habitat (regression coefficient $=6.68 \pm 3.31, r^{2}$ $=0.34)$. In this analysis, the Salton Sea had the largest residual, which indicated many more riparian birds than expected based on the extent of riparian habitat.

\section{DISCUSSION}

There is general agreement that riparian habitats are critically important to en route landbirds crossing arid and semi-arid landscapes in southwestern North America (Skagen et al. 1998, Finch and Yong 2000, Flannery et al. 2004). In fact, during spring migration, avian communities in some riparian sites are comprised of approximately $90 \%$ en route migrants (Flannery et al. 2004). Across the range of our study, however, riparian sites differed substantially with respect to many attributes of avian community structure during the spring migration period, including species richness and composition, densities, and the proportion of en route species. Extent of canopy cover in the study sites strongly influenced species richness, with gallery cottonwood forests of multilayered vegetation hosting the greatest numbers of species; however, this trend may be due, in part, to the extensive survey effort in gallery forests.

Our findings suggest that migration patterns in the western United States-Mexico border region are complex. Several species, such as the Yellow Warbler and the Song Sparrow, varied in abundance across the range of the study. In general, riparian associates were more abundant at sites in the western part of the study range than at sites in the east and were only minimally influenced by species biogeography. In contrast, abundance patterns of nonriparian species were

\footnotetext{
$\leftarrow$

a Riparian affinity category: 1 = riparian obligates and 'associates', generally linked with riparian habitats; 2 $=$ not considered a riparian-associated species, per se, but often found in riparian woodlands or other riparian habitats; and 3 = generally not associated with riparian habitats.
} 
TABLE 4. Fit of global model and effects of longitude and latitude (model-averaged coefficient \pm SE and effect score) on abundance estimates of 34 species from survey data. Species are listed by descending order of coefficient for longitude. See Table 1 for species codes.

\begin{tabular}{|c|c|c|c|c|c|c|}
\hline \multirow[b]{2}{*}{ Species code } & \multirow[b]{2}{*}{$\begin{array}{l}\text { Riparian } \\
\text { affinity }^{\text {a }}\end{array}$} & \multirow[b]{2}{*}{$\begin{array}{l}\text { Global } \\
\text { model } r^{2}\end{array}$} & \multicolumn{2}{|c|}{ Longitude } & \multicolumn{2}{|c|}{ Latitude } \\
\hline & & & Coefficient & $\begin{array}{l}\text { Effect } \\
\text { score }^{b}\end{array}$ & Coefficient & $\begin{array}{l}\text { Effect } \\
\text { score }^{b}\end{array}$ \\
\hline SOSP & 1 & 0.83 & $0.42 \pm 0.09$ & $2^{c}$ & $-0.23 \pm 0.25$ & $0^{c}$ \\
\hline COYE & 1 & 0.62 & $0.27 \pm 0.10$ & $2^{c}$ & $-0.22 \pm 0.28$ & $0^{c}$ \\
\hline WEFL & 1 & 0.52 & $0.24 \pm 0.07$ & 2 & $0.06 \pm 0.21$ & $0^{\mathrm{c}}$ \\
\hline NOOR & 1 & 0.58 & $0.23 \pm 0.08$ & 2 & $-0.08 \pm 0.23$ & $0^{\mathrm{c}}$ \\
\hline WAVI & 2 & 0.79 & $0.21 \pm 0.04$ & $2^{c}$ & $-0.09 \pm 0.12$ & $0^{\mathrm{c}}$ \\
\hline YWAR & 1 & 0.58 & $0.20 \pm 0.12$ & $1^{\mathrm{c}}$ & $-0.66 \pm 0.32$ & -1 \\
\hline NAWA & 3 & 0.40 & $0.19 \pm 0.08$ & $2^{c}$ & $0.02 \pm 0.23$ & $0^{\mathrm{c}}$ \\
\hline OCWA & 2 & 0.46 & $0.19 \pm 0.07$ & 2 & $0.26 \pm 0.20$ & $0^{\mathrm{c}}$ \\
\hline WEKI & 2 & 0.67 & $0.17 \pm 0.07$ & 2 & $-0.25 \pm 0.19$ & $0^{\mathrm{c}}$ \\
\hline WETA & 3 & 0.62 & $0.16 \pm 0.06$ & $2^{c}$ & $0.28 \pm 0.16$ & $0^{\mathrm{c}}$ \\
\hline WIWA & 1 & 0.46 & $0.12 \pm 0.06$ & $1^{\mathrm{c}}$ & $-0.25 \pm 0.17$ & $0^{\mathrm{c}}$ \\
\hline TOWA & 3 & 0.50 & $0.12 \pm 0.05$ & $2^{c}$ & $-0.11 \pm 0.14$ & $0^{\mathrm{c}}$ \\
\hline LAZB & 2 & 0.40 & $0.08 \pm 0.05$ & $1^{\mathrm{c}}$ & $0.17 \pm 0.13$ & 0 \\
\hline WCSP & 3 & 0.14 & $0.07 \pm 0.08$ & 0 & $0.23 \pm 0.20$ & 0 \\
\hline BTYW & 3 & 0.27 & $0.07 \pm 0.10$ & 0 & $-0.01 \pm 0.26$ & $0^{c}$ \\
\hline YRWA & 3 & 0.56 & $0.06 \pm 0.07$ & $0^{\mathrm{c}}$ & $0.17 \pm 0.19$ & $0^{c}$ \\
\hline BEVI & 1 & 0.60 & $0.04 \pm 0.11$ & $0^{c}$ & $-0.77 \pm 0.25$ & -2 \\
\hline HAFL & 3 & 0.82 & $0.03 \pm 0.02$ & $0^{c}$ & $-0.12 \pm 0.06$ & $1^{\mathrm{c}}$ \\
\hline HEWA & 3 & 0.43 & $0.03 \pm 0.04$ & 0 & $-0.01 \pm 0.11$ & 0 \\
\hline LISP & 1 & 0.76 & $0.03 \pm 0.04$ & 0 & $-0.18 \pm 0.11$ & $0^{c}$ \\
\hline RCKI & 3 & 0.46 & $0.03 \pm 0.09$ & $0^{\mathrm{c}}$ & $0.24 \pm 0.24$ & $0^{\mathrm{c}}$ \\
\hline WEWP & 2 & 0.52 & $0.01 \pm 0.05$ & $0^{\mathrm{c}}$ & $-0.03 \pm 0.14$ & $0^{\mathrm{c}}$ \\
\hline YBCH & 1 & 0.52 & $-0.01 \pm 0.12$ & $0^{c}$ & $-0.55 \pm 0.29$ & -1 \\
\hline MGWA & 2 & 0.48 & $-0.03 \pm 0.05$ & $0^{c}$ & $0.21 \pm 0.11$ & 1 \\
\hline GTTO & 3 & 0.81 & $-0.03 \pm 0.04$ & 0 & $-0.34 \pm 0.10$ & $-2^{\mathrm{c}}$ \\
\hline SOVI & 2 & 0.62 & $-0.04 \pm 0.06$ & $0^{\mathrm{c}}$ & $0.07 \pm 0.16$ & $0^{c}$ \\
\hline BRSP & 3 & 0.16 & $-0.05 \pm 0.08$ & $0^{\mathrm{c}}$ & $-0.02 \pm 0.21$ & $0^{c}$ \\
\hline HETH & 2 & 0.37 & $-0.05 \pm 0.06$ & $0^{\mathrm{c}}$ & $0.25 \pm 0.16$ & $0^{c}$ \\
\hline LEGO & 2 & 0.62 & $-0.05 \pm 0.07$ & $0^{c}$ & $-0.21 \pm 0.19$ & $0^{\mathrm{c}}$ \\
\hline GRFL & 3 & 0.76 & $-0.06 \pm 0.02$ & -2 & $0.01 \pm 0.07$ & $0^{\mathrm{c}}$ \\
\hline NRWS & 1 & 0.60 & $-0.07 \pm 0.09$ & 0 & $0.57 \pm 0.21$ & 2 \\
\hline BHGR & 2 & 0.77 & $-0.11 \pm 0.06$ & -1 & $0.42 \pm 0.15$ & 2 \\
\hline DUFL & 3 & 0.74 & $-0.12 \pm 0.04$ & $-2^{c}$ & $0.26 \pm 0.12$ & 1 \\
\hline CHSP & 3 & 0.71 & $-0.16 \pm 0.07$ & -2 & $-0.01 \pm 0.21$ & $0^{\mathrm{c}}$ \\
\hline
\end{tabular}

a Riparian affinity category: 1 = riparian obligates and 'associates', generally linked with riparian habitats; 2 $=$ not considered a riparian-associated species, per se, but often found in riparian woodlands or other riparian habitats; and 3 = generally not associated with riparian habitats.

b Effect score based on whether CI spans zero: $0=$ no effect, $1=$ small effect $(90 \%$ CI does not span zero), 2 = large effect $(95 \%$ CI does not span zero).

${ }^{\mathrm{c}}$ Effect scores are consistent between survey and capture data.

strongly influenced by biogeographical attributes, including the extent and locations of breeding and wintering ranges.

A current paradigm of habitat selection during migration implies that species biogeography, weather patterns, and prevailing winds are of overriding importance at large spatial scales (Hutto et al. 1985, Moore and Aborn 2000). This paradigm espouses a hierarchical view in which a migrant follows a migration route that mini- mizes its flight time and distance, uses broadscale habitat factors (such as food availability) as initial cues for selecting habitats, and selects actual foraging sites at a finer spatial scale based on intrinsic habitat factors (Hutto 1985, Moore et al. 1995). Our findings for nonriparian species are consistent with this hypothesis.

Our finding that many riparian associates increased in abundance in western riparian zones relative to those in the intermountain west con- 


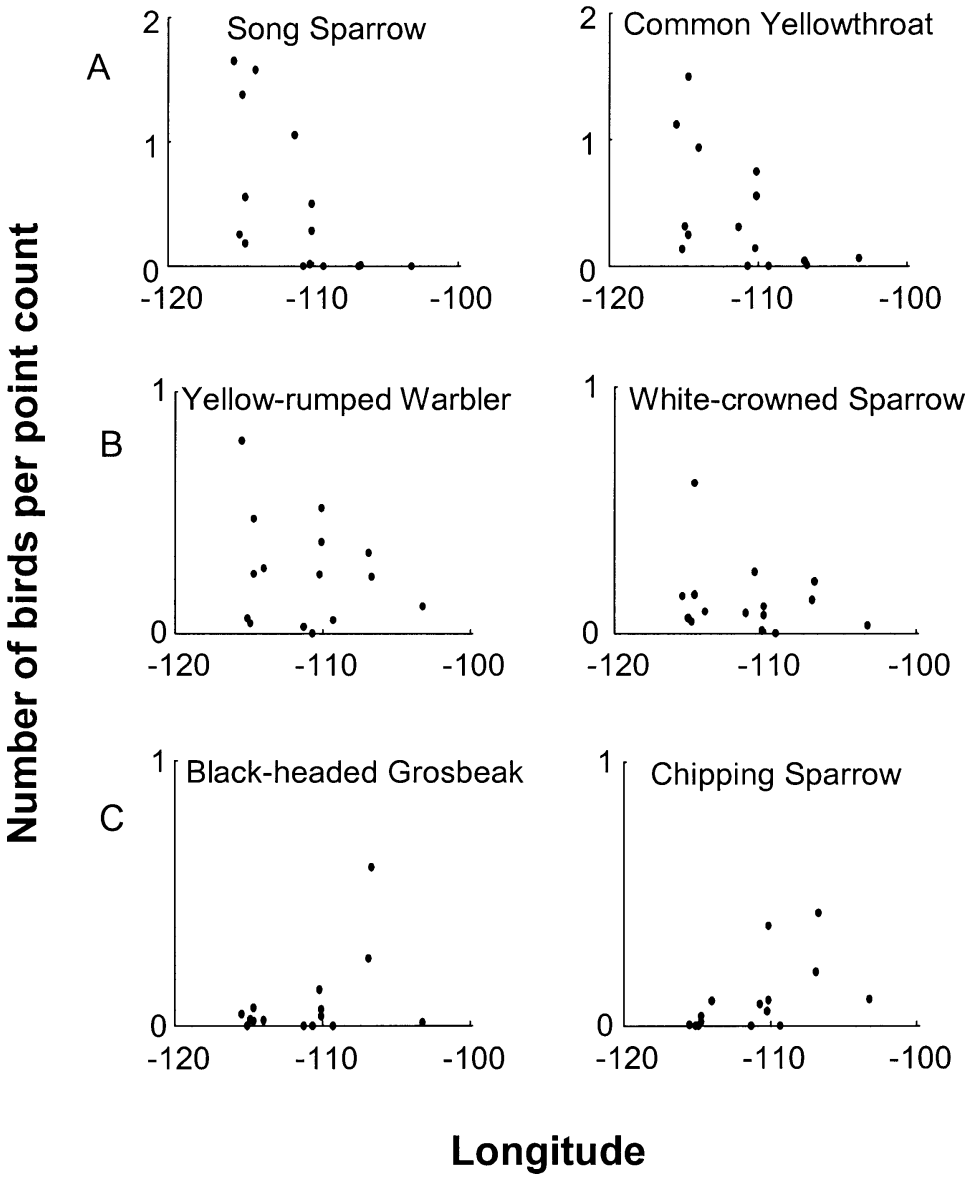

FIGURE 2. Mean number of birds per 10 point counts by longitude for six bird species detected at 15 survey sites in southwestern United States and northern Sonora, Mexico, 1975-2003. Examples of species whose abundances A) increased with increasing longitude, B) appeared unaffected by longitude, and C) increased with decreasing longitude.

tradicts expectations based primarily on patterns of species biogeography, and instead suggests that riparian associates refined their direct migration paths to coincide with areas that provide the best riparian stopover habitat. Most individuals are "programmed" to follow a migratory pathway between their breeding and nonbreeding areas (Moore et al. 1995), but the evolution of currently-used migration paths may have been influenced by intrinsic factors that determine suitability of stopover habitat along the way (Hutto 1985). We hypothesize that riparian associates trade off time and distance minimization (Alerstam and Lindstrom 1990; Lindstrom and Alerstam 1992) to enhance the probability of encountering riparian habitats, whereas nonriparian birds minimize time and distance un- constrained by distribution of riparian vegetation on the landscape. We do not know whether birds are unwavering in their adherence to historical, largely innate migration routes or whether they are capable of actively making refinements in ecological time in response to landscape change. Berthold et al. (1992) describe a novel migration route of Blackcap (Sylvia atricapilla), illustrating that migratory changes can evolve rapidly. Active refinements in habitat selection are consistent with, although at a larger scale than, observations of foraging plasticity and small-scale movements near stopover sites (Martin and Karr 1990, Wiedner 1992).

By viewing the extent of riparian habitat in the landscapes surrounding our study sites, we may gain insight into our observed westerly 
TABLE 5. Fit of global model and effects of longitude and latitude (model-averaged coefficient \pm SE and effect score) on capture rates of 33 species from banding data. Species are listed by descending order of coefficient for longitude. See Table 1 for species codes.

\begin{tabular}{|c|c|c|c|c|c|c|}
\hline \multirow[b]{2}{*}{ Species code } & \multirow[b]{2}{*}{$\begin{array}{l}\text { Riparian } \\
\text { affinity }^{\mathrm{a}}\end{array}$} & \multirow[b]{2}{*}{$\begin{array}{l}\text { Global } \\
\text { model } r^{2}\end{array}$} & \multicolumn{2}{|c|}{ Longitude } & \multicolumn{2}{|c|}{ Latitude } \\
\hline & & & Coefficient & $\begin{array}{l}\text { Effect } \\
\text { score }^{b}\end{array}$ & Coefficient & $\begin{array}{l}\text { Effect } \\
\text { score }^{b}\end{array}$ \\
\hline SOSP & 1 & 0.68 & $0.35 \pm 0.07$ & $2^{c}$ & $0.21 \pm 0.26$ & $0^{\mathrm{c}}$ \\
\hline WEFL & 1 & 0.40 & $0.26 \pm 0.20$ & 0 & $-0.40 \pm 0.33$ & $0^{c}$ \\
\hline WAVI & 2 & 0.51 & $0.21 \pm 0.09$ & $2^{c}$ & $-0.45 \pm 0.30$ & $0^{c}$ \\
\hline COYE & 1 & 0.66 & $0.18 \pm 0.09$ & $1^{\mathrm{c}}$ & $0.05 \pm 0.29$ & $0^{c}$ \\
\hline WETA & 3 & 0.41 & $0.16 \pm 0.08$ & $1^{\mathrm{c}}$ & $-0.25 \pm 0.29$ & $0^{c}$ \\
\hline LEGO & 2 & 0.22 & $0.15 \pm 0.09$ & $0^{c}$ & $0.05 \pm 0.34$ & $0^{c}$ \\
\hline WIWA & 1 & 0.15 & $0.15 \pm 0.10$ & $1^{\mathrm{c}}$ & $0.02 \pm 0.35$ & $0^{c}$ \\
\hline NAWA & 3 & 0.55 & $0.14 \pm 0.07$ & $1^{\mathrm{c}}$ & $-0.39 \pm 0.24$ & $0^{\mathrm{c}}$ \\
\hline YWAR & 1 & 0.33 & $0.13 \pm 0.07$ & $1^{\mathrm{c}}$ & $-0.26 \pm 0.26$ & 0 \\
\hline BHGR & 2 & 0.23 & $0.13 \pm 0.08$ & 1 & $-0.26 \pm 0.27$ & 0 \\
\hline OCWA & 2 & 0.37 & $0.11 \pm 0.09$ & 0 & $-0.22 \pm 0.32$ & $0^{c}$ \\
\hline TOWA & 3 & 0.62 & $0.11 \pm 0.04$ & $2^{c}$ & $-0.14 \pm 0.13$ & $0^{c}$ \\
\hline HAFL & 3 & 0.63 & $0.09 \pm 0.06$ & $0^{c}$ & $-0.76 \pm 0.19$ & $-2^{c}$ \\
\hline LAZB & 2 & 0.62 & $0.09 \pm 0.03$ & $2^{c}$ & $-0.28 \pm 0.12$ & -2 \\
\hline BTYW & 3 & 0.58 & $0.08 \pm 0.04$ & 1 & $-0.17 \pm 0.15$ & $0^{c}$ \\
\hline WEWP & 2 & 0.26 & $0.06 \pm 0.04$ & $0^{\mathrm{c}}$ & $0.15 \pm 0.13$ & $0^{c}$ \\
\hline NOOR & 1 & 0.05 & $0.05 \pm 0.08$ & 0 & $0.23 \pm 0.28$ & $0^{c}$ \\
\hline SOVI & 2 & 0.42 & $0.04 \pm 0.04$ & $0^{c}$ & $-0.16 \pm 0.14$ & $0^{c}$ \\
\hline WEKI & 2 & 0.23 & $0.03 \pm 0.03$ & 0 & $-0.05 \pm 0.10$ & $0^{c}$ \\
\hline SPTO & 3 & 0.43 & $0.02 \pm 0.09$ & 0 & $-0.04 \pm 0.30$ & 0 \\
\hline BEVI & 1 & 0.13 & $0.01 \pm 0.06$ & $0^{\mathrm{c}}$ & $-0.25 \pm 0.18$ & 0 \\
\hline RCKI & 3 & 0.57 & $0.01 \pm 0.04$ & $0^{c}$ & $-0.04 \pm 0.14$ & $0^{c}$ \\
\hline HETH & 2 & 0.19 & $-0.02 \pm 0.07$ & $0^{c}$ & $-0.35 \pm 0.22$ & $0^{c}$ \\
\hline YRWA & 3 & 0.46 & $-0.02 \pm 0.07$ & $0^{c}$ & $-0.02 \pm 0.23$ & 0 \\
\hline BRSP & 3 & 0.42 & $-0.03 \pm 0.03$ & $0^{c}$ & $0.11 \pm 0.09$ & $0^{c}$ \\
\hline GRFL & 3 & 0.07 & $-0.03 \pm 0.04$ & 0 & $-0.01 \pm 0.13$ & $0^{c}$ \\
\hline MGWA & 2 & 0.08 & $-0.02 \pm 0.08$ & $0^{c}$ & $0.18 \pm 0.33$ & 0 \\
\hline CHSP & 3 & 0.45 & $-0.05 \pm 0.06$ & 0 & $-0.18 \pm 0.20$ & $0^{c}$ \\
\hline YBCH & 1 & 0.48 & $-0.06 \pm 0.09$ & $0^{c}$ & $-0.73 \pm 0.26$ & $-2^{c}$ \\
\hline WCSP & 3 & 0.86 & $-0.09 \pm 0.04$ & -1 & $0.30 \pm 0.14$ & 1 \\
\hline LISP & 1 & 0.30 & $-0.11 \pm 0.06$ & -1 & $-0.28 \pm 0.23$ & $0^{c}$ \\
\hline DUFL & 3 & 0.46 & $-0.20 \pm 0.06$ & $-2^{c}$ & $0.03 \pm 0.24$ & 0 \\
\hline GTTO & 3 & 0.84 & $-0.21 \pm 0.04$ & -2 & $-0.46 \pm 0.13$ & $-2^{c}$ \\
\hline
\end{tabular}

a Riparian affinity category: 1 = riparian obligates and 'associates', generally linked with riparian habitats; 2 $=$ not considered a riparian-associated species, per se, but often found in riparian woodlands or other riparian habitats; and 3 = generally not associated with riparian habitats.

b Effect score based on whether CI span zero: $0=$ no effect, I = small effect (90\% CI does not span zero), $2=$ large effect $(95 \%$ CI does not span zero).

${ }^{\mathrm{c}}$ Effect scores are consistent between survey and capture data.

trends in abundance and capture rates. In general, sites with more riparian forest in the surrounding landscape yielded greater abundances of riparian birds, and sites with little riparian forest had few riparian birds, as would be expected if birds chose landscapes with greater extents of suitable habitats. At the Salton Sea, however, many more riparian birds were present than expected based solely on extent of riparian habitat, suggesting that migrants also concentrate at oases in landscapes with limited riparian vegeta- tion. We view these findings as preliminary because of the limited ability of NLCD to resolve the smaller narrower riparian habitat patches.

The accuracy of NLCD depictions of riparian vegetation in the western United States is untested. For San Pedro River survey sites, we compared estimates of extent of riparian based on NLCD data with an estimate based on the Arizona Statewide Riparian Inventory and Monitoring database (ASRIM) in a delineated area of comparable size (Skagen et al. 1998). Also 
TABLE 6. The effects of biogeographic and habitat predictors on a derived variable (longitude coefficient from previous regression analyses; higher values represent greater abundances or capture rates in the west) of 34 and 33 species from survey and capture data, respectively. Values are presented as the model-averaged coefficient \pm SE.

\begin{tabular}{|c|c|c|c|c|c|c|}
\hline & \multicolumn{3}{|c|}{ All species } & \multicolumn{3}{|c|}{ Riparian affinity ${ }^{\mathrm{a}}$ categories 2 and 3} \\
\hline & Coefficient & $95 \% \mathrm{CI}$ & $\begin{array}{l}\text { Effect } \\
\text { score }^{b}\end{array}$ & Coefficient & $95 \% \mathrm{CI}$ & $\begin{array}{l}\text { Effect } \\
\text { score }^{b}\end{array}$ \\
\hline \multicolumn{7}{|c|}{ Survey (34 species, 10 riparian associates) } \\
\hline $\begin{array}{l}\text { Northern extent of } \\
\text { breeding range }\end{array}$ & $0.004 \pm 0.003$ & $-0.002,0.010$ & 0 & $0.005 \pm 0.003$ & $-0.001,0.011$ & 1 \\
\hline $\begin{array}{l}\text { Eastern extent of } \\
\text { breeding range }\end{array}$ & $0.002 \pm 0.001$ & $0.000,0.004$ & 2 & $0.005 \pm 0.002$ & $0.001,0.009$ & 2 \\
\hline Winter distribution & $-0.009 \pm 0.033$ & $-0.075,0.058$ & 0 & $-0.054 \pm 0.027$ & $-0.110,0.001$ & -1 \\
\hline Riparian affinity & $-0.064 \pm 0.026$ & $-0.117,-0.011$ & -2 & & & \\
\hline \multicolumn{7}{|c|}{ Capture (33 species, 9 riparian associates) } \\
\hline $\begin{array}{l}\text { Northern extent of } \\
\text { breeding range }\end{array}$ & $0.002 \pm 0.004$ & $-0.006,0.010$ & 0 & $0.001 \pm 0.003$ & $-0.005,0.007$ & 0 \\
\hline breeding range & $0.000 \pm 0.002$ & $-0.004,0.004$ & 0 & $0.002 \pm 0.003$ & $-0.004,0.007$ & 0 \\
\hline Winter distribution & $-0.010 \pm 0.017$ & $-0.044,0.024$ & 0 & $-0.039 \pm 0.029$ & $-0.099,0.020$ & 0 \\
\hline Riparian affinity & $-0.027 \pm 0.012$ & $-0.050,-0.003$ & -2 & & & \\
\hline
\end{tabular}

based on Landsat data with a 30-m spatial resolution, the ASRIM database was evaluated on the ground and further refined. The two estimates were comparable at $0.26 \%$ and $0.3 \%$ from NLCD and ASRIM data, respectively. Because the accuracy of NLCD in representing riparian habitats remains in question, however, future studies would greatly benefit from landscape databases with finer spatial resolution, greater ability to distinguish riparian vegetation types, and verification of vegetation types.

To truly identify landbird migration routes across the southwest, we advocate broadscale, coordinated research based on stratified random site selection across riparian and other habitat types to address potential effects of elevation and habitat type. Important covariates, such as survey effort and timing of studies, also must be incorporated into study design. This approach would allow extrapolations of avian densities across entire landscapes, thereby improving upon the more typical nonrandom site selection that tends to emphasize 'hotspots'. We are careful to note that the greater site-specific abundance estimates do not reflect the overall distribution of birds during migration, hence they are of limited use in defining a specific migration route. Large site-specific abundances in some western sites may have been due to birds concentrating in a smaller portion of the landscape, and in other regions lower numbers may have resulted because birds were dispersed throughout more extensive habitat.

Southwestern lowland riparian areas, which cover less than $1 \%$ of the landscape, are heavily used by many en route Nearctic-Neotropical migrant birds (Skagen et al. 1998, Finch and Yong 2000, Flannery et al. 2004). Proactive conservation of those riparian corridors may assure that future habitat stopover requirements of many western neotropical migrant birds will continue to be met. Surprisingly, however, we still know little about use of other habitat types during spring and fall migration and how migrant-habitat relations vary with spatial scale. Sparse knowledge of migrant-habitat relationships, coupled with evidence that migrants use some 'corridors' more than others, underscores the need for a broad scale and coordinated research effort to clarify these patterns so that conservationists can maximize the benefits of land acquisition and restoration efforts. 


\section{ACKNOWLEDGMENTS}

We are very grateful to the generous individuals who provided or prepared data and ideas for this project, including S. Allerton, W. C. Barrow, Jr., G. Bodner, C. T. Collins, C. Kristina Ecton, E. Gómez-Limón, C. E. Gordon, K. J. Gutzwiller, D. L. Hawksworth, R. Hazlewood, O. Hinojosa-Huerta, W. H. Howe, D. Kaschube, W. Leitner, L. McGrath, M. Means, C. O’Brien, M. L. Scott, W. Turner, H. A. Walker, N. Warnock, and S. Wilbor. T. Giles and D. Schneider provided data management and GIS support. Funding for this meta-analysis was provided by the U.S. Geological Survey Quick Response Program (recommended by the U.S. Fish and Wildlife Service Region 6, USFWS Helena Field Office, and Sonoran Joint Venture) and PPLMontana. Funding for collection of the Tucson area data was provided by the Arizona Fish and Game Department, and funding for the Santa Cruz River surveys in Sonora was provided by the Programme Ecoregional-Desierto Sonorense, Sonora. We thank the Tucson Bird Count volunteers for their many hours of data collection, the Arizona Audubon Society for their survey data from the Santa Cruz River in Arizona, as well as the bird banders who captured birds at MAPS stations in the desert southwest region: B. Allen, S. Bakeman, T. Campbell, C. Gugagli, A. Hubbard, J. Kahl, C. Otahal, N. Paloma, W. Sakai, M. Whitfield.

\section{LITERATURE CITED}

Alerstam, T., AND A. LindSTRÖM. 1990. Optimal bird migration: the relative importance of time, energy and safety, p. 331-351. In E. Gwinner [ED.], Bird migration: physiology and ecophysiology. Springer-Verlag, New York.

BARLOW, J. C. 1980. Patterns of ecological interactions among migrant and resident vireos on the wintering grounds, p. 79-107. In A. Keast and E. S. Morton [EDs.], Migrant birds in the Neotropics: ecology, behavior, distribution, and conservation. Smithsonian Institution Press, Washington, DC.

Berthold, P., A. J. Helbig, G. Mohr, and U. QuerNER. 1992. Rapid microevolution of migratory behaviour in a wild bird species. Nature 360:668670.

Burnham, K. P., And D. R. Anderson. 2002. Model selection and inference: a practical informationtheoretic approach. 2nd ed. Springer, New York.

Dobkin, D. S., AND A. C. Rich. 1998. Comparison of line-transect, spot-map, and point-count surveys for birds in riparian habitats of the Great Basin. Journal of Field Ornithology 69:430-443.

Dobkin, D. S., AND B. A. WILCOX. 1986. Analysis of natural forest fragments: riparian birds in the Toiyabe Mountains, Nevada, p. 293-300. In J. Verner, M. L. Morrison, and C. J. Ralph [EDs.], Wildlife 2000: modeling habitat relationships of terrestrial vertebrates. The University of Wisconsin Press, Madison, WI.

Evans, P. R., N. C. Davidson, T. Piersma, And M. W. PIENKOWSKI. 1991. Implication of habitat loss at migration staging posts for shorebird populations. Acta International Ornithological Congress 20: 2228-2235.
FInCH, D. M., AND W. Yong. 2000. Landbird migration in riparian habitats of the Middle Rio Grande: a case study. Studies in Avian Biology 20:88-98.

FitZPATRICK, J. W. 1980. Wintering of North American tyrant flycatchers in the Neotropics, p. 67-78. In A. Keast and E. S. Morton [EDS.], Migrant birds in the Neotropics: ecology, behavior, distribution, and conservation.Smithsonian Institution Press, Washington, DC.

FlanNery, M. E., S. L. Guers, T. Gardali, N. Nur, AND G. R. GEUPEL. 2004. Landbird migration at the Salton Sea: the value of desert riparian habitat. Studies in Avian Biology 27:106-115.

FLEISCHNER, T. L. 1994. Ecological costs of livestock grazing in western North America. Conservation Biology 8:629-644.

GreEnBERG, R. 1983. The role of neophobia in determining the degree of foraging specialization in some migrant warblers. American Naturalist 122: 444-453.

Howell, S. N. G., AND S. WebB. 1995. A guide to the birds of Mexico and northern Central America. Oxford University Press, Oxford, UK.

HutTo, R. L. 1980. Winter habitat distribution of migratory landbirds in western Mexico, with special reference to small, foliage-gleaning insectivores, p. 181-203. In A. Keast and E. S. Morton [EDS.], Migrant birds in the Neotropics: ecology, behavior, distribution and conservation. Smithsonian Institution Press, Washington, DC.

HutTo, R. L. 1985. Habitat selection by nonbreeding, migratory landbirds, p. 455-476. In M. L. Cody [ED.], Habitat selection in birds. Academic Press, Inc., Orlando, FL.

HutTo, R. L. 1992. Habitat distributions of migratory landbird species in western Mexico, p. 221-239. In J. M. Hagan III and D. W. Johnston [EDS.], Ecology and conservation of Neotropical migrant landbirds. Smithsonian Institution Press, Washington, DC.

Hutto, R. L. 1998. On the importance of stopover sites to migrating birds. Auk 115:823.

Hutto, R. L. 2000. On the importance of en route periods to the conservation of migratory landbirds. Studies in Avian Biology 20:109-114.

Kelly, J. F., And R. L. Hutto. 2005. On songbird migration in western North America: a case study of wood warblers. Condor 107:197-211.

Kelly, J. F., R. Smith, D. M. Finch, F. R. Moore, AND W. YONG. 1999. Influence of summer biogeography on wood warbler stopover abundance. Condor 101:76-85.

Knopf, F. L., R. R. Johnson, T. Rich, F. B. SAMson, AND R. C. SZARo. 1988. Conservation of riparian ecosystems in the United States. Wilson Bulletin 100:272-284.

KRUEPER, D. J. 1993. Effects of land use practices on western riparian ecosystems, p. 321-330. In D. M. Finch and P. W. Stangel [EDS.], Status and management of Neotropical migratory birds. USDA Forest Service General Technical Report RM-229.

Lindström, A., AND T. Alerstam. 1992. Optimal fat loads in migrating birds: a test of the time-mini- 
mization hypothesis. American Naturalist 140: 477-491.

Lovette, I. J., S. M. ClegG, And T. B. Smith. 2004. Limited utility of mtDNA markers for determining connectivity among breeding and overwintering locations in three neotropical migrant birds. Conservation Biology 18:156-166.

Martin, T. E., AND J. R. KARR. 1990. Behavioral plasticity of foraging maneuvers of migratory warblers: multiple selection periods for niches? Studies in Avian Biology 13:353-359.

Maptech, InC. [ONLINE]. 1989-2005. Maptech MapServer Maps and Charts. <http://mapserver. maptech.com/homepage/index.cfm $>$ (26 January 2004).

Moore, F. R., And D. A. Aborn. 2000. Mechanisms of en route habitat selection: how do migrants make habitat decisions during stopover? Studies in Avian Biology 20:34-42.

Moore, F. R., S. A. Gauthreaux Jr., P. Kerlinger, AND T. R. Simons. 1995. Habitat requirements during migration: important link in conservation, $\mathrm{p}$. 121-144. In T. Martin and D. M. Finch, [EDS.], Ecology and management of Neotropical migratory birds. Oxford University Press, New York.

Moore, F. R., And T. R. Simons. 1992. Habitat suitability and stopover ecology of Neogropical landbird migrants, p. 345-355. In J. M. Hagan III and D. W. Johnson [EDS.], Ecology and conservation of Neotropical migrant landbirds. Smithsonian Institution Press, Washington, DC.

Moore, F. R., AND W. Yong. 1991. Evidence of foodbased competition among passerine migrants during stopover. Behavioral Ecology and Sociobiology 28:85-90.

Multi-Resolution Land Characteristics ConsorTIUM. 2000. National Land Cover Characterization. $<$ http://landcover.usgs.gov/natllandcover.asp $>$ (10 February 2005).

OHMART, R. D. 1994. The effects of human-induced changes on the avifauna of western riparian habitats. Studies in Avian Biology 15:273-285.
Petrt, D. R. 2000. Habitat use by landbirds along Nearctic-Neotropical migration routes: implications for conservation of stopover habitats. Studies in Avian Biology 20:109-114.

Poff, L. N., J. D. Allan, M. B. Bain, J. R. Karr, K. L. Prestegand, B. D. Richter, R. E. Sparks, AND J. C. Stromberg. 1997. The natural flow regime: a paradigm for river conservation and restoration. Bioscience 47:769-784.

Rich, T. D., C. J. Beardmore, H. Berlanga, P. J. Blancher, M. S. W. Bradstreet, G. S. Butcher, D. W. Demarest, E. H. Dunn, W. C. Hunter, E. E. Iñigo-Elias, J. A. Kennedy, A. M. Martell, A. O. Panjabi, D. N. Pashley, K. V. Rosenberg, C. M. Rustay, J. S. Wendt, and T. C. Will. 2004. Partners in Flight North American Landbird Conservation Plan. Cornell Laboratory of Ornithology. Ithaca, NY.

Skagen, S. K., R. Hazlewood, and M. L. Scott. In press. The importance and future condition of western riparian ecosystems as migratory bird habitat. In C. J. Ralph and T. D. Rich [EDS.], Bird conservation implementation and integration in the Americas. USDA Forest Service General Technical Report RM-191.

Skagen, S. K., C. P. Melcher, W. H. Howe, And F. L. KNOPF. 1998. Comparative use of riparian corridors and oases by migrating birds in southeast Arizona. Conservation Biology 12:896-909.

The Nature Conservancy. 2004. Conservation by design: Sonoran Desert ecoregional plan. <http:// nature.org/aboutus/howwework/cbd/science/ art14339.html $>$ (26 January 2005).

Wiedner, D. S., P. Kerlinger, D. A. Sibley, P. Holt, J. Hough, AND R. CRossley. 1992. Visible morning flights of Neotropical landbird migrants at Cape May, New Jersey. Auk 109:500-510.

Yong, W., D. M. Finch, F. R. Moore, And J. F. Kelly. 1998. Stopover ecology and habitat use of migratory Wilson's Warblers. Auk 115:829-842. 